\title{
SPELLBOUND? THE SECRET MESSAGE OF LOLLY WILLOWES
}

\author{
Emma Robson
}

Sylvia Townsend Warner had much in common with her eponymous heroine in Lolly Willowes, which marks it as a very personal manifesto. There are clues to be found in Harman's biography of Warner, published 1989, which make it increasingly clear that witcheraft, typically seen as the 'secret' which eludes Laura Willowes on her journey of discovery, is only a motif, and that the real secret has to be uncovered amidst the richly dense intertextual material in the novel, like any other buried treasure. Warner's erudition was both 'phenomenal and natural' and every page is rich in meaning, every word judiciously considered (Harman 1991, p.20).

It is likely that Lolly Willowes was written as part of Warner's own grieving process after her father's death, 'My father died when I was twenty-two, and I was mutilated' (Steinman 2001, p.220). Her biographer 
describes how Warner's grief on her father's death was 'forced ... underground' (Harman 1991, p.37). This essay argues that Lolly Willowes is a novel about a bright and sheltered woman who suffers psychological damage because she is given no time to grieve after the death of her father. Despite the tone of Lolly Willowes, Warner was dealing with serious issues, albeit they are buried in intertextuality. On a close examination the novel is complex and bitter-sweet. Lolly Willowes is realist novel with an almost post-modern twist.

The concept of a witch is metonymy for radically transmitted female values (Sempruch 2008, p.18), and even though Warner lived through the early days of feminism, the idea was relevant because the sense of women being 'adverse' or 'in opposition' was made clear in the famous Malleus Maleficartm. Written in 1486 to help magistrates convict witches, this treatise stated that there were more witches of the feminine sex because they were defective, having been formed from a bent rib, bent in a contrary direction to a man (Scmpruch 2008, p.21). Warner lampoons Malleus: Laura remarks that she had not always agreed that man was the noblest work of nature, but Mr Saunter showed her it was true, 'So Adam had been the noblest work when he walked out among the beasts... with all his ribs about him, his equilibrium untroubled by Eve' (Warner 2012, p.109). Having set up Adam, the barb hits sharply between the ribs: 'Perhaps, like other noble works, man is rare. Perhaps there is only one of him at a time: first Adam; now Mr Saunter' (p.110). The status of the witch is thus rectified and Malleus Maleficarum is suitably hammered. In fact, 'So much did Mr Saunter remind Laura of Adam, that he made her feel like Eve' (p.110). When 'Eve' later aligns herself with Satan in Lolly Willowes, Warner wittily consigns the Bible and Christian patriarchy to the dustbin of history.

Laura's background is a significant factor in understanding how she has been psychologically damaged. She was a solitary child from a "quiet household' with no opportunity to mix with girls of her 
own age, such that neighbours worried she would 'grow up eccentric' (Wamer 2012, p.17). She did, and found it difficult to relate socially because the "local tea parties and balls ... did not give her an opportunity of mentioning anything that she had learnt from Locke on The Understanding or Glanvil on Witches' ( p.22). Although she was intelligent, her interests isolated her. Likewise Warner also lacked a peer group and lived 'on the fringes of a world given over to boys', such that she became 'self-possessed, isolated and unusual' (Harman 1991, pp.22, 20). Warner's profile almost exactly fits that of her protagonist, lending substance to the argument that Laura is an alter ego who, like Warner, suffered a psychological 'mutilation' on the death of her father (Steinman 200I, p.220).

On the day of the funeral Laura either has an "out of body' experience, or completely withdraws from consciousness. Significantly, this happens immediately after Laura says 'In the midst of death we are in life' (Warner 2012, p.35), inverting the usual position, signalling a metaphorical 'death'. Harker's 2010 paper based on Damasio's theory of consciousness also supports the notion that during the funeral Laura's state of consciousness would have been operating at the 'core' level, which does not have a sense of time. Laura wanted a 'backward look but Caroline prevented her' (p.35). The name of the officiating vicar at the funeral, $\mathrm{Mr}$ 'Warbury', may also be a reference to shock or trauma induced by the funcral.

As Laura leaves the funeral she experiences the 'yearning of an outcast' for the 'old home', which is probably explained by the proximity of the grave of her mother and father. Her link with the churchyard is also strong, because she went on 'solemn and delicious' expeditions with her mother to maintain the graves, where she learned the family history such that 'her mind told the tale of them, for she knew them well' (pp.36, 34). After her mother's death she went to the family burial ground alone, and 'half yielded her mind to the fancy that her dead mother ... was sitting a little apart in the shade' 
(p.34). These emotional links arguably cause Laura to feel a vicarious attachment, which is in line with her idea that 'In the midst of death we are in life', because it reverses the usual notion of existence and links her more among the dead than the living (p.35).

Subsequently, there is strong evidence that Laura: suffers from her inability to grieve. After the death of her mother she strove to comfort her father and to "be grownup, to be clcar-headed and watchful', crying only in the potting shed, "where a pair of old gardening gloves repeated to her the shape of her mother's hands' (p.19). By contrast, her brother James' sorrow was demonstrable, such that Laura and her father' sat like 'two good children in the presence of a more grown-up grief than they could understand' (p.20). Laura's attempts to emulate her father and support him after the death of her mother may have stifled her own gricving process. Harman points out that Warner suffered a similar experience on the death of her father, which 'forced [her] grief underground' (Harman 1991, p.37). Rebecca West wrote of similar issues in Return of the Soldier in 1918, so this was topical, but significantly, Laura's condition remains undiagnosed throughout the novel and reveals itself only sporadically, in her desire to capture an clusive 'secret', generally understood to be the fact that she is a witch. This essay argues that the secret is the missing element in Laura's consciousness which would allow her to grieve. The thoughts of Brewer the gardener support the argument for psychological damage: he saw that Laura was 'dashed and broken by bad weather' (Warner 2012, p.38).

Freud stated in Ego that a full recovery required the bereaved to take 'the lost other into the structure of one's own identity, a form of preserving the lost object in and as the self' (Clewell 2004, p.61). Laura's reactions at the funcral would suggest that her sense of self was impaired. The fact that she is on a journey of self-discovery and ultimately believes herself to be a witch, further suggests that she feels a want of identity until that point. Her life in London made it hard for her to grieve: 'In Somerset she had grieved over her father's death. In London it was 
retracted into sudden realisations of her loss. She thought that sorrow would be her companion for many years... now it visited her like sudden snowstorms' (Warner 2012, p.38). Another interesting point is that Laura is "restless and tormented' during autumn, around the anniversary of her father's death, but could not 'explain what she felt' (p.66).

If the funeral was the onset of a psychological trauma then the novel admits of a different reading from that typically assigned, and is actually a journey to emotional well-being. Whilst Laura can function in society, her family regard her as eccentric and she is unable to form bonds with them (Kahn 2002, p.175). Whereas we see clear affection demonstrated by Laura before the funeral, such as her stooping to Tito to "lay her face against his prickly bib and his smooth, warm head' we see little demonstration of affection afterwards (Warner 2012, p.8). Subsequently she thought Fancy and Marion 'dull children', 'believed she would like Caroline if she could only understand her", and understood Henry but could not 'much like him' (p.46). Her best relationship was with Titus, with whom she was 'glad still to be friends' (p.78). In addition to this emotional disconnection from her family, Laura has what Caroline refers to as 'daydreams' when her body sat 'cosy with Caroline and Henry but her mind walked by lonely sea-bords' (p.80). We are told that 'depressed though she was' she did not seck beauty in her 'daydreams', but was 'groping after something which eluded her experience' (p.67).

Subsequent to the funeral, Laura's behaviour strangely mirrors the texts she read as a girl in the library of Lady Place, where there were 'no restrictions on what she read' (p.22). Two of these books were 'Locke on the Understanding' and 'Glanvil on Witches' both of which shape her thinking (p.23). In his work An Essay Concerning Human Understanding, Locke argued that there was no such thing as innate knowledge, and that everything derived from the senses. Laura uses sensations as part of her thinking process and this is seen in her decision to move to Great Mop. She looks into a shop and 
sees 'rough-skinned' pears, 'earthy' turnips and 'glistening' plums, and in her dream-orchard she senses an 'ache' (p.73). Later, she longed to 'stroke her hands over' the mop-headed chrysanthemums (p.74). This riot of the senses inspires her momentous idea to move to Great Mop, and Laura 'stood very still to make sure of her sensations', which is a very literal application of Locke (p.74). Laura is also naturally 'superstitious', so it is not unsurprising that Glanvil's theory of the existence of witches would influence her imagination, and lead to her becoming a witch (p.32).

It is notable that Laura did not need to become a witch to achieve 'peace' in Great Mop, which she did swiftly, but that even then, she had yet to 'find out her own secret, if she had one' (p.106). Laura's scarch for her secret is reflected in the books she borrows from Mrs Leak's library, including Enquire Within Upon Everything and Mehalah. In a chapter entitled 'Mourning' in Mehalah, the eponymous heroine works 'in a mechanical manner' after a loved one's death, making 'no lamentation over his loss' (Baring-Gould 1969, p.95). Her mother thinks her unfecling but 'A fecble querulous woman like she was quite unable to measure the depth of her daughter's heart, and understand its working. The result was that she read them wrongly, and took false soundings' (Baring-Gould 1969, p.95). The reference to Mehalah suggests that Laura's failure to grieve is the core of her story. Significantly, the second book borrowed signals to the reader that an 'enquiry' is to be made. The novel's intertextuality is the modernist route by which the reader is meant to detect Laura's innermost thoughts, which would otherwise remain unavailable due to her psychological state.

It may also be the case that when she is at Great Mop Laura begins to recover incrementally, such that the knowledge of her 'secret' grows in her core consciousness. For example, shortly after she borrows Mehalah the wind 'calls her out' at night (Warner 2012, p.111). The landscape is personified and given a supernatural tone: the fir plantation "chants some never- 
ending rune', a goods train is 'pulsating' up the hill and the blood is 'drumming" in her ears', which generate a trance-like atmosphere (p.111). The rhythmic nature of the language inexorably propels Laura towards an ultimate possibility, namely her secret. Laura feels she must 'yield herself' to escape the terror induced by the 'wicked sound', which 'expressed something eternally outcast', suggestive of Satan's fall in Paradise Lost p.112). In addition, the moon is out 'hunting' overhead, so we assume it is a Hunter Moon with magical properties. This recalls Artemis, huntress and goddess of the moon, but the language is moving more towards the Satanic. Finally, the moon 'plunged towards her' through the clouds, "Now! Now!" said the moon', however, the secret had 'eluded her again' (p.113).

Laura finds 'peace' and 'absolution' at Great Mop before she becomes a witch; she knelt down to smell the cowslips and 'the weight of all the unhappy years seemed for a moment to weigh her down...; she trembled, understanding how miserable she had been; and in another moment she was released' (p.123). Laura's tears 'absolved her', a metaphor for baptism, and re-birth, with a second chance for self-fulfilment (p.123). In the following months she "lived in perfect idleness and contentment' (pp.123, 124). Laura realised that she necd not 'triumph mentally over her tyrants' but neither could she forgive them, largely because it was not their fault (p.124). The problem began with 'Society, the Law, the Church' and filtered down to the 'Architect of Apsley Terrace, and half a dozen other useful props of civilisation' (p.124). This acceptance shows that Laura is moving towards recovery, Laura's idyll is spoiled when Titus comes to live in Great Mop. In frustration, she takes a solitary walk and hides herself in an unpleasant triangular field. The triangle signifies the unity of the feminine, maiden, mother and crone (Reid-Bowen 2007, p.68). Laura's cry 'Is there no help?' is to the ether, in the hope that 'any grimly favourable power' will hear it (p.138). Laura's anger shows some of the 'animation' and 'spirit' of her youth (p.24). However when she is 
scratched by a kitten later that evening, she conjures up a Satanic interpretation. This helps her, because when she believes she is a witch, her hope is renewed because she has a protector in Satan.

Laura finds her first Sabbath as dull as the Hunt Balls of her youth and is once more the social misfit. She gets lost on the way home, having flouted the Sabbath, and 'with her soul full of doubts' p.205). There she meets a gamekeeper, walking with a 'slow and easy gait' ( p.168). $\mathrm{He}$ is kind and reassuring, offering her help if she needs it, which prompts her to ask where he can be found, to which he replies, 'You will always find me in the wood' (p.170). Laura realises that he is Satan, 'no longer as a hunter, but as a guardian' (p.171). This meeting occurs during the liminal moment just before dawn, when Laura has been up all night, and is troubled by doubt. Satan thus arrives in her hour of need, but the text signals that Laura is an unreliable narrator, in that Satan appears where "she had met the badger' (p.168). The only badger in the text is the one that killed Mr Saunter's hens. Satan may be as unreal as the badger.

The next Satanic event is a series of 'small bothers' culminating in a wasp-attack upon Titus, who is rescued by his future wife, and leaves Great Mop (p.174). This is a very un-satanic outcome, and the clue in the text is that the wasp-attack takes place on the site of 'Folly Wood'. Laura is content once more, and has, thematically, concluded her journey of self-discovery as a witch. However she has still not found the elusive secret.

At this point Laura meets up with Satan for the last time. He is kind, interested and above all, encourages Laura to talk, 'not that I may know your thoughts, but that you may' (p.197). Laura is having rudimentary psychotherapy. In response to his question 'Tell me... what you think' she responds, at length, with Warner's feminist manifesto (p.211). In Satan's world, the patriarchy is challenged because women come first: 'It is we witches who count. We have more need of you. Women have such vivid imaginations, and lead such dull lives' (p.192). That is the central message of Lolly 
Willowes, accounting for Laura's miscrable years at Apsley Terrace. The most powerful metaphor is that women are as dangerous as 'dynamite', knowing in their hearts how 'extraordinary' they are, and Laura has a positive message too, in that the potential of women is 'incalculable' (p.195).

The particular issue for Laura is that patriarchal institutions have damaged her to such a degree that she is now pontificating to Satan, claiming his protection because every other institution she might look to has failed her. Hence Satan undermines patriarchy, because he has done what they could not and given "succour to a decayed gentlewoman' (p.192).

Arguably, the need for the conversation is spurred by Laura's need to discover her secret. Satan is Laura's coping mechanism, identified by her powerful imagination, through which she has the potential for recovery. Having got rid of Titus, she is on the track of her 'secret'. It begins with the squashing of a midge. Satan cxclaims, "Dead!" This brings a narrative disjunction, with direct reported speech abandoned for free indirect discourse. The tone also changes; 'The word dropped into her mind like a pebble thrown into a pond....rocking the shadows of familiar things' (p.199). Laura reflects that 'There might be some questions that even the Devil could not answer. She turned her cyes to him with their question', but Satan gets up to go ( p. 243). Laura thinks that Satan 'looked as if he did not know much more about it than she did herself' (p.245). The conversation ends on this ironic note, Satan having played his part. Laura has to work out her secret for herself, but is at least on track.

This conversation takes place at Maulgrave Folly. This not only refers again to 'Folly', but 'maul' and 'grave' are reminiscent of Laura's pain at her father's funeral. Another factual contradiction which marks unreliable narration is that this Satan had a 'slouching and prowling gait' which Laura recognised as 'familiar', despite its lack of correspondence with the 'slow and easy gait' of the first Satan (pp.187, 168). Finally, Laura meets Satan 
leaving the grave of a 'Satanic Baronet', so it is plausible this motif could be suggestive to her 'vivid imagination'. The only evidence of Satan's presence is a rampion flower he 'had held in his hand' and some 'flattened grass', which is easily explained by the fact that Laura has arisen and sat down again herself.

There is considerable evidence to suggest that Laura's Satanic hallucinations are due to the psychological damage caused by her failure to properly grieve the death of both parents. But Warner allows just enough contrary evidence, so that the reader can choose to believe, or not. The novel ends on an uplifting message, and Laura's final conversation with the devil is a joyous and witty one, in which she is finally able to coherently articulate her twenty years of frustration and unhappiness. But it is bittersweet, in that Laura may finally get to say her piece, but was anyone really listening?

Psychological damage caused by a failure to grieve was elearly in Warner's mind when she referenced Mehalah. This puts it beyond doubt that there is nothing about Lolly Willowes which is fantasy. It is a novel about a woman coming to know herself and who is trying to find 'the secret country of my mind', meaning that part of the mind which, in a Freudian sense, is closed off (Warner p.112). The novel is firmly set in realism, with clements of a post-modern twist, in keeping with Warner's general prescience. As Perenyi points out, 'in Warner herself there was more than a touch of the witch' (1985 page no.?). Warner played up to interviewers about being a witch, which was odd given she complained to her friend David Garnett that she had tried to make a sword with Lolly Willowes 'only to be told what a pretty pattern there was on the blade' (Waters p.xi). But Warner may not have wanted to give the 'secret' away when the book was first published. Lolly Willowes is almost a detective story, with all the clues in the text and intertexts, but there are a lot of misleading trails, and witchcraft is most misleading trail of all, because, like Laura, if the reader settles for that as an answer, then they will never find the secret country of Laura's mind. We know that Laura did not 
ccase her search, because she says that "There might be some questions that even the Devil could not answer' (p.245).

As a feminist novel Lolly Willowes is full of invention, and Warner is quick to sniff out the hypocrisy of the Christian patriarchy. She has Mrs Leak 'call up' characters like the Witch of Endor, and Adam is metaphorically poked in the ribs. She takes the archetypal biblical story which justified the Christian subjugation of women for 2000 years, and subverts it to her feminist cause. Satan says to Laura, '(I'll have one of your apples if I may. They are a fruit I am particularly fond of)' (Warner 2012, p.192). If Satan is forced to eat his own apple, then the message is a positive one. Wamer sees the potential for active, imaginative women: that they are 'extraordinary and incalculable' (Warner 2012, p.195).

As I write this conclusion on Walpurgisnacht it is important to look back to the muddled theology of witcheraft history and see how once again Warner has turned it on its head. A significant aspect of the Satanic theme in Lolly Willowes is that it springs from Glanvil's Saducismus Triumphatus, a work which appears to be Laura's reference point for her knowledge of witches. However, Glanvil's proposition for the existence of witches sprang from his belief that 'disbelief in witcheraft was but one step in the path to atheism. No witches, no spirits, no immortality, no God' (Notestein 2014, p.205). He saw witches and witchcraft as a means of upholding the Christian faith. Warner's reference to Glanvil casts a diabolical spell over Lolly Willowes: whether or not you believe Laura is a witch, Warner and her feminist manifesto succeeds in its aim either way. If you don't believe, then on Glanvil's terms it is a blow to the hegemony of patriarchal religion. If you do believe, the radically transmitted female values of the witch deliver a blow to patriarchal society. Either way, Warner wins. 


\section{WORKS CITED}

BARING-GOULD, S. (1969) Mehalah: A Story of the Salt Marshes. Chatto \& Windus.

Clewell, T. (2004) "Mourning Beyond Melancholia: Freud's Psychoanalysis of Loss.' Joumal of the American Psychoanalytic Association 52.1 pp.43-67. Web. 20 Apr. 2014.

http://apa.sagepub.com/content/52/1/43.full.pdf+html?hw shib2=authn\%3A1418777786\%3A20141215\%253Aa7a3

2157-a9f2-4b47-a234-

ce567e6ae $9 \mathrm{c} 3 \% 3 \mathrm{~A} 0 \% 3 \mathrm{~A} 0 \% 3 \mathrm{~A} 0 \% 3 \mathrm{Ak} 09 \mathrm{kllm} 7 \mathrm{UhqhaqV}$

Apt50nA\%3D\%3D

DAMASIO, A. (2000) The Feeling of What Happens: Body and Emotion in the Making of Consciousness. New York: Harcourt.

FREUD, S. (2001) Complete Psychological Works of Sigmund Freud, Vol 14: "On the History of the Post Psychoanalytic Movement". "Papers on Metapsychology" and Other Works London: Vintage Classics.

GARNETT, R. (Ed) (1994). Sy/via and David: The Townsend Warner/Garnett Letters. London: SinclairStevenson

GLANVIL, J. (2010) Sadducismus Triumphatus: Or; a Full and Plain Evidence, Concerning Witches and Apparitions. In Two Parts. The Fourth Edition, with Additions. Gale ECCO.

HARKER, J. (2010) 'The Limits of the Mind: Cognition and Narrative Form in the Modernist Novel.' 11. pag. Google Scholar. Web. 23 Mar. 2014. http://escholarship.org/uc/item/6tb3dln 0

HARMAN, C. (1991) Sylvia Townsend Warner: A Biography. London: Minerva.

(Ed.) (1994) The Diaries of Sylvia Townsend Warner. London: Chatto \& Windus. HOULSTON, G. (2003) Enquire within upon Everything 1890: A Comprehensive Guide to the Necessities of Domestic Life in Victorian Britain. (1890) United Kingdom: Old House. 
KAHN, M. (2002) Basic Freud: Psychoanalytic Thought for the Twenty First Century. New York: Basic Books.

KRAMER, H., and J. SPRENGER (2009) Malleus Maleficartm. Trans. Montague Summers. n.p. IAP, 2009. LOCKE, J. 'An Essay Concerning Human Understanding.' (2007) N. p. 2007. Web. 28 Apr. 2014. http://www.earlymoderntexts.com/pdfs/locke 1690book2. pdf

NOTESTEIN, W. (2014) 'A History of Witchcraft in England From 1558 To 1718.' Scribd n. pag. Web. 30 Sept. 2014.

https://www.scribd.com/doc/247147860/A-History-of-

Witchcraft

PERENYI, E. (1985) 'The Good Witch of the West. The New York Review' of Books 18 July. The New York Review' of Books. Web. 1 May 2014.

http:/www.nybooks.com/articles/archives/1985/jul/18/the -good-witch-of-the-west/

REID-BOWEN, P. (2007) Goddess as Nature: Towards a Philosophical Thealogy. Aldershot, Hampshire; Burlington VT: Ashgate

SEMPRUCH, J. (2008) Fantasies of Gender and the Witch in Feminist Theory and Literature. West Lafayette, Ind.: Purdue University Press.

STEINMAN, M. (Ed.) (2001) The Element of Lavishness: Letters of Sylvia Townsend Warner and William Maxwell, 1938-1978. Washington, D.C.: Counterpoint.

WARNER, S.T. (2012) Lolly Willowes: Or The Loving Huntsman. London: Virago.

WATERS, S. (2012) Introduction. Lolly Willowes: Or The Loving Huntsman by Sylvia Townsend Warner. London: Virago.

WEST, R. (1998) The Retum of the Soldier. London: Penguin.

WOODHAM-SMITH, C. (1971) The Reason Why. Harmondsworth: Penguin. 